\title{
The Relationship between Peace, State and Democracy: Bosnia and Herzegovina as a Deviant Case
}

\begin{abstract}
The conventional wisdom in political theory for a long time was that the establishment of peace is a prerequisite for state building and that state building is a prerequisite for the development of democracy. This conventional wisdom of the relationship between peace, state and democracy has been disturbed several times in Bosnia and Hercegovina from the first democratic elections in 1990 to the present day. This short overview of political attitudes of the three constitutive ethnic communities - Muslims/Bosniaks, Serbs and Croats - and their elected political representatives shows that there is no consensus on the state and on the political order, but only on the political democracy.
\end{abstract}

Keywords: Bosnia and Herzegovina, peace, state, democracy, war, consensus

\section{The relationship between peace, democracy and state in political theory}

For a long time there had been no fundamental disputes about the relationship between peace, state and democracy in political theory. It was conventionally considered that the establishment and consolidation of peace were prerequisites for state building and that state building was a prerequisite for the development of democracy. However, this relationship was again actualised as part of the consideration of the democratic transformation of autocratic political regimes in Eastern Europe in the 1990s when also the state order in that part of the continent collapsed. Whereas Eastern Europe consisted of eight states before the beginning of the democratic transition, there were altogether 21 states in that area in 2018. If the eight new states in the Asian part of the former Soviet Union are added to this number, what one gets is a tectonic disorder of international state order in Eastern Europe and Central Asia. The quick creation 
of the 24 new states, encompassing quite a large number of weak or failed states and "defective democracies", opened up the questions of the nature of their statehood and democracy, which are generalised in the relationship between state and democracy.

In their discussion about democratic transformation, Linz and Stepan (1992; 1996) drew attention to the fact that the crisis of undemocratic regimes in Eastern Europe was connected to the crisis of the existing states. They brought into the discussion the problem of stateness which did not exist in the older transitional literature on Latin America and South Europe since the states there did not fall apart when the authoritarian political regimes were transformed into the democratic ones. Linz and Stepan came to the conclusion that the problem of stateness emerges when a considerable part of the population does not accept the existing state, be it democratic or undemocratic, as a legitimate political community to which it owes loyalty. They concluded that "in fact, agreements about stateness are prior to agreements about democracy" (Linz, Stepan, 1992, pp. 123-124). They are not necessary in undemocratic regimes in which the power is not derived from free competitive elections so that existing secessionist forces cannot express their goals within the framework of "normal politics". Such regimes and states can rule over large parts of the population without their consent, i.e. by force. Nonetheless, democratic regimes cannot solve the problem of statehood in such a way. The larger the number of people who do not accept the existing state, the greater the necessity to reconstitute it in order to create conditions for consolidating democracy within it. Linz and Stepan (1996, p. 17) expressed the relationship between state and democracy in the canonical dictum: "Democracy is a form of governance of a modern state. Thus, without a state, no modern democracy is possible". The statement "if there is no state, there is no democracy" was soon stylised into the dictum stateness first. Linz and Stepan also reminded about two constitutive features of a state: (a) a complete monopoly of a sovereign state over the force continuum on its territory; and (b) a social consensus on who are the citizens, i.e. who makes the demos. The stateness has become the "prerequisite for democracy".

Linz (1997, p. 117) repeatedly stated that there is no democracy without a state, be it a national or a multi-national, warning about the fact that it must not be forgotten how democracy evolved or was introduced into societies in which the modern state had been developing for centuries. He went a step further by formulating the dictum "no state, no Rechtsstaat, no democracy" (Linz, 1997, p. 118). Since political theory distinguishes between the terms 'stateness' (Staatlichkeit) and 'the rule of law' (Rechtsstaat), it could be concluded that Linz broadened the former dictum by introducing two prerequisites of democracy: stateness and the rule of law. These two terms can, but do not have to overlap. In 
a causal relationship, stateness can be determined as a prerequisite of democracy and stylised into the dictum "there is no rule of law without stateness". Rechtsstaat or the rule of law is conventionally determined as one of the crucial features of a democratic state. Based on such considerations, Møller and Skaaning (2011, pp. 3-4) identified four groups of attributes of democracy: electoral rights, political freedoms, the rule of law and social rights. They are constitutive for four types of democracy: electoral rights, the way they were determined by Schumpeter (1976), are constitutive for electoral democracy; political rights, the way they were defined by Dahl (1971), constitute polyarchy; the rule of law, the way it was defined by O'Donnell (2001), is constitutive for liberal democracy; social rights, derived from Marshall's (2009) definition of civil rights, constitute social democracy. Stateness by itself does not create democracy but it is a necessary prerequisite of democracy. There are undemocratic states, but there are no non-state democracies.

\section{The relationship between peace, state and democracy in Bosnia and Herzegovina}

The conventional relationship between peace, state and democracy was disturbed several times in Bosnia and Herzegovina (B-H). The first disturbance happened when in 1990 a consensus on democracy, but not the one on the state, was reached. That was the main cause of the civil war which is evidence that there was no real consensus on peace. All the sides which later on participated in the armed conflict accepted in 1990 that B-H should be organized as a democratic political community. Nevertheless, they did not agree on its future status: whether it should remain within the Yugoslav state, whatever it is and whoever it was comprised of, or whether it should become a sovereign state. Since this fundamental question was highly disputable, the established consensus on peace was a short-term one. Between 1990 and 1992, before the beginning of the most intensive phase of violent conflicts, the initial fragile consensus on peace and democracy was falling apart. Hence, in the period of the intensive internationalised civil war between 1992 and 1995 there was no consensus on any of the matters - peace, state or democracy. It was only towards the end of the war, under pressure of international military and political actors, that a triple consensus started to build up gradually, but unevenly.

Initially, political representatives of the Muslim/Bosniak and Croatian community reached a partial consensus on peace, state and democracy, formalised by the Washington Agreement of 1994, which was valid only in one part of the 
pre-war state territory called the Federation of B-H. The Federation was a kind of "partial state", created under strong international, above all American, political and diplomatic pressure which was motivated not only by regional, but also by broader geopolitical interests. Reuter (1997, p. 159) claims that by creating the Federation, the USA wanted to reach three goals: (a) to prevent coming into being "a pure Muslim state on the European soil"; (b) to overcome hard problems of territorial delimitation between the Croats and the Bosniaks; (c) to elegantly solve the complex problem of the access of the Bosniaks to the Adriatic Sea. While the USA was putting pressure on the Bosniak side to get rid of Islamic fundamentalists who came to Bosnia to practice jihad (Kohlmann, 2004), it was at the same time strongly pressing Croatia to stop the military support for the Bosnian Croats in the conflict with the Muslims/Bosniaks. The USA threatened Croatia that they would stop supporting its territorial integrity and its reintegration of the territories occupied by the Serbs into the constitutional order of the state (Mearsheimer, Van Evera, 1995, p. 18; Chandler, 2000, p. 43; Gromes, 2007, p. 147). Chollet (2007, p. 73) says that observers called the Washington Agreement "a wedding under armed threat", whereas the President of Croatia, Franjo Tuđman called it "a heavy cross to bear" because of the growing opposition among the Croats to the cooperation with the Muslims/Bosniaks and to staying in $\mathrm{B}-\mathrm{H}$.

Under strong international pressure and because of their defeats in military operations, the Serbs joined the consensus on peace by signing the Dayton Peace Agreement in 1995. Hence, the process of state-building was carried out in two stages: at the beginning only one part of it, the Federation was constructed which Republika Srpska joined later on. The two constitutive entities of the current B-H came into being in different ways and in different periods. Republika Srpska emerged by force during the war and the Federation by a peace agreement after the Muslims/Bosniak-Croatian "civil war within the civil war". The first one is a genuine war creation of Bosnian Serbs which international actors were forced to recognize in order to exact the consent of the Serbs to stay within B-H, whereas the second one is a non-genuine intra-conflict creation which was imposed on both the Croats and the Bosniaks from outside. Neither of the two constitutive parts of the state had existed prior to the war. Both were created during it, what makes them war creations par excellence. Bojkov (2003, p. 43) claims that the primary goal of international actors was "to keep the country together at all costs".

The main international actors, above all the USA which controlled the peace process in $\mathrm{B}-\mathrm{H}$, were convinced that the Bosnian-Herzegovinian state could be reconstructed through the establishment of democratic political institutions without prior consensus on peace and state. The peace agreement was not ratified, either in a plebiscite or in the Parliamentary Assembly of B-H since the 
lack of consensus on the state could cause its collapse. Moreover, at the time of the conclusion of the Dayton Peace Agreement in 1995 there was also no consensus on peace between the three belligerent sides, Serbs, Croats and Muslims/ Bosniaks, "instead, the conflict had essentially remained unresolved - both on the battlefield and the negotiating table" (Weller, Wolff, 2006, p. 3). Since the Dayton Peace Agreement was understood as a transformative conflict settlement, the conflicts were expected to be resolved through its application when - with a massive presence, supervision and intervention of international military and civil actors in the country - they would be transformed by peaceful and democratic means, and when mutual conflicts about state and constitutional issues would be resolved through the politics of accommodation and compromise.

Based on these assumptions, the institutional or "physical" reconstruction of the state was initiated. Its main means was an intensive policy of electoralism (after 1995 mandates of the main political bodies, the Parliamentary Assembly and the three-member Presidency of the state, lasted for two years) whose goal was not only the democratic formation of political institutions. Through political and legal interventions of international actors in the political and social processes, the policy of electoralism also aimed at weakening exclusive nationalist parties and depolarising ethnic identities, on the one hand, as well as at strengthening alleged multi-ethnic actors and civic identity, on the other, in order to substantively change political institutions and their policies. Nevertheless, such institutionalisation of democracy did not result in "creating the state in the minds of its citizens", i.e. in "ideational aspect of statebuilding" (Keranen, 2014, p. 127). Nobody wanted or knew how to accomplish this task. Constitutional consociational arrangements proved to be a guarantee for peace, preventing deep ethnic cleavages from turning into new conflicts (Kasapović, 2005). However, they were incapable of overcoming these cleavages and of developing awareness of belonging to one state which could, eventually, lead to a consensus on the state. Among other things, the extensively diversified post-war civil society was not able to accomplish this eminent task because it was crisscrossed by particular and private interests and often loyal all to its foreign financiers. Traditional institutions which outlived the war, such as churches and cultural bodies dug themselves even deeper in their religious-ethnic trenches. Since activities of international actors were mainly perceived as the attack from outside and from above on the existing national entities and collective identities, political institutions were getting more and more empty, thus becoming symbolic bodies without real political power (Basta, 2016). In this way, the consensus on democracy, as the only consensus which seemed to exist, was dissolving. 


\section{Attitudes towards the state and political order}

Since the state was constructed under direct pressure of external actors, the inner consensus on it was questionable. As it is a matter of an ethnically deeply divided post-conflict society, the state community should be legitimated by a "double majority" - the majority of B-H citizens and the majority of members of each of the three constitutive peoples: Bosniaks, Serbs and Croats - in a plebiscite. Since it was not created as an expression of a sovereign political will of the three peoples, B-H had only "negative sovereignty" based on persistent efforts of powerful international actors to make it survive as a state (Hayden, 2005, p. 239). And since it was "democracy without demos", the established political order was also not an expression of the will of a sovereign people. Although it is stated in Annex 4 of the General Peace Agreement, which serves as the Constitution of $\mathrm{B}-\mathrm{H}$, that the constitutional order is an expression of the political will of Bosniaks, Croats and Serbs, this Constitution was not ratified, either in a referendum or in a democratic elected representative body. It was imposed by an "international decree" and signed by the presidents of Croatia and Serbia as well as by "the leader of Bosnian Muslims" so that two out of three signatories were not B-H citizens (Hayden, 2005, pp. 242-243). In such conditions, the question of the existence of the will of the civil majority and the majority in the three constitutive ethnic communities that $\mathrm{B}-\mathrm{H}$ exists as a common state is determined in an indirect way, above all through the electoral support of voters to certain political parties and through survey results of political attitudes of citizens.

\section{The Bosniak Position}

There is no doubt that $\mathrm{B}-\mathrm{H}$ has a constant support of the Bosniaks, with the exception of some war episodes when it seemed that the Party of Democratic Action, the leading Bosniak party which had the entire power over the territories controlled by the Bosniak Army of $\mathrm{B}-\mathrm{H}$, was inclined to consider the partition of the state (Komšić, 2006, p. 229). Bose (2002, p. 170) is right when he claims that those ideas were contextually conditioned: by the intensification of the conflict in 1993-1994, unfavourable military position of Bosniak forces and uncertain war outcome. The Bosniaks generally wanted a strongly integrated state in which citizens of all ethnic groups would share a common "Bosnian consciousness" (Cohen, 1998, p. 104). All Bosniak parties are against the Dayton Constitution and for the establishment of a liberal unitary state with non-ethnic regions or without them: "Most of the Bosniaks demand a new and more centralized constitution to replace Dayton Accords" (Berg, 2013, p. 470). In other 
words, "major Bosniak political parties reject the ethno-institutional organization of the Bosnian state" (Basta, 2016, p. 954). This attitude was directly influenced by the breakup of Yugoslavia and indirectly by that of the Soviet Union and Czechoslovakia, which deepened the scepticism towards ethnic federations as institutional "producers of secessionism", despite the fact that they were undemocratic federations or pseudo-federations (Skalnik Leff, 1999; Hale, 2004).

According to the findings of an empirical investigation of 2005, only $19.7 \%$ of the Bosniaks thought that the Dayton Constitution should not be changed, a convincing majority wanted B-H to be a unitary state divided only into municipalities (55.6\%) or into regions and municipalities (11.7\%), and only a small number accepted a cantonization without entities $(4.1 \%)$ and a federation or a confederation (2.8\%) (ÓTuathail, O’Loughlin, Djipa, 2006, pp. 68, 72). Such attitudes overlap with political programmes of all Bosniak parties so that they were profiled as de facto anti-systemic and anti-constitutional actors. In short, the Bosniaks support a radical review of the constitutional order which would transform B-H from an asymmetrical consociational (con)federation into a unitary liberal state.

\section{The Serbian position}

The Serbian side preferred the partition of B-H before, during and after the war, but it gave up the secession under strong international military, political, diplomatic and economic pressure on the Bosnian Serbs as well as on Serbia. Bieber (2008, pp. 10, 176) claims that "a majority of Serbs [...] prefers secession", Gromes (2011, p. 260) that "a majority of Serbs refuses... to share one state with the Bosniaks", and Petersen (2011, p. 245) that "most Serbs do not wish to live in a political entity where Bosniaks are the plurality, let alone majority". According to the mentioned public opinion survey of 2005 , even $76 \%$ of the survey participants in Republika Srpska wanted it to be separated from B-H and annexed to Serbia. The majority of the Serbian elite and Bosnian Serbs considers B-H an illegitimate and artificial creation (Bose, 2002, p. 3). They attach to Republika Srpska the status of a half independent state entity or they consider it an interim transitional arrangement which leads to the secession from B-H. ${ }^{1}$

Analysts often called Republika Srpska a de facto state because from 1991 to 1995 it controlled the territory it had militarily occupied, it had the inner sup-

Milorad Dodik, a president of Republika Srpska and the most influential Serbian politician in B-H after the war, says that "we don't need this kind of country. We don't want to be in this B-H". Referring to "neutral surveys", he claims that " $88 \%$ of the people in Republika Srpska want to leave B-H" (Dodik, 2011, pp. 17-18). Hence, he is constantly calling for a referendum on secession of Republika Srpska from B-H. 
port of its citizens and it was capable of offering public services necessary for the life of the people (Pegg, 2004; Zahar, 2004; Berg, 2012). Kølsto (2006, p. 723) included it in internationally unrecognized quasi-states: political entities without an outer, but with an inner sovereignty which enables them to survive and is based on the support of the local population created by propaganda, and on the creation of a special identity, and on the support of an outer patronizing state as well as on the fact that the state it was created from is itself weak. Caspersen (2012, p. 125) thinks that the Dayton Agreement formally annulled the de facto statehood of Republika Srpska created in the war. On the other hand, the Agreement left Republika Srpska broad independent powers, including the right to establish special relationships with Serbia which brought it very close to the status of a "state within a state". From a wartime status of a de facto state, Republika Srpska was transformed into a peacetime status of a state within a state which kept many features of the statehood built up in the war: its borders and territory, political and legal institutions, the infrastructure which enables it to offer its citizens security, education, health and other services, sustainability and coherence which are more visible than in the state in which it is situated.

Baer $\left(2000\right.$, p. 47) concludes that already at the end of the $20^{\text {th }}$ century it was not clear whether the Bosnian Serbs support the political option of "secession plus stateformation" or the option "secession plus integration". Rajčević (2012, p. 72) claims that the option of "a peaceful dissolution and formation of new states" is completely open "which would effectively end the break-up of Ex-Yugoslavia". This opens up two possibilities for the Serbs: secession and annexation to Serbia or secession and gaining state independence of Republika Srpska. Although one and united Serbian state remains a political ideal, the Serbs from Republika Srpska have nothing against the idea that their entity becomes a second Serbian state in the Balkans. This would follow a broader trend of forming two national states on the peninsula: the Greeks have Greece and Cyprus, the Turks have Turkey and a de facto state the Turkish Republic of Northern Cyprus, and the Albanians have Albania and Kosovo. For now, the Serbs remain supporters of the consociational order in B-H, but not in Republika Srpska. Since the Dayton Constitution ensures exactly this kind of solution, it has, as long as it exists, the strongest support exactly among the Serbs.

\section{The Croatian position}

The position of the Croats towards $\mathrm{B}-\mathrm{H}$ is the most unclear to researchers. Firstly, the Croats voted in the pre-war referendum together with the Muslims for B-H as an independent state. Secondly, in the war, they mainly behaved so as to bring into question their pre-war attitude towards the state and with 
the establishment of the Croatian Community of Herzeg-Bosnia i.e. the Croatian Republic Herzeg-Bosnia, they also expressed potential secessionist intentions (Hoare, 1997; Ribičič, 2001). Thirdly, after signing the Washington and the Dayton Peace Agreements the Croatian political elite behaved inconsistently: sometimes radicalising its positions, as in the attempt of setting up the Croatian Self-Government in 2001 as de facto the third or Croatian ethnical entity, sometimes supporting the restructuring of the existing Federation into a community of more ethnical cantons. Sometimes it seemed as if it would be satisfied with limited interventions in the existing political order, such as changing the way of electing members of the Presidency (Kasapović, 2016).

Immediately after the end of armed conflicts, a majority of Croats did not accept B-H. One survey showed that right before the 1996 post-conflict elections even $89 \%$ of the Croats believed that their future is connected more to Croatia than to B-H (Bardos, 2013, pp. 172-173). According to the findings of the mentioned survey from 1997, even $79 \%$ of the Croats did not support their remaining in B-H, wanting Croatian ethnical areas to be annexed to Croatia (Gromes, 2007, pp. 209, 332; see also: Schneckener, 2002, p. 209; Hayden, 2005, pp. 229, $233,241)$. Later surveys also showed that some parts of the Croatian population "either support irredentism towards Croatia or the establishment of their own political entity in Bosnia" (Berg, 2013, p. 470). Ten years after the signing of the peace agreement, the Dayton Constitution enjoyed very weak support of the Croats: only $7.6 \%$ of survey participants thought that it should not be changed at all, $13.6 \%$ considered it negative and wanted it to be suspended, whereas $63.2 \%$ advocated for a new constitution which would give Bosnian-Herzegovinian Croats their own federal or confederal unit (Ó Tuathail, O’Loughlin, Djipa, 2006, pp. 68, 72). "Similarly to their Serb peers, Croat nationalist elites see Bosnia as a multinational state and view the narrative of a civic Bosnian political community with suspicion" (Basta, 2016, p. 962). Petersen (2011, p. 245) concludes that "for many Croats, the solution is to exit". Nevertheless, the current position of the Croatian majority can be described as a demand for an own ethnical entity within B-H. Contrary to the Bosniaks and Serbs who are consociationalists only there where they are in minority, the Croats are consociationalists in the Federation as well as in the state since both political communities are in minority.

\section{Conclusion: Consequences of the disagreement of the three sides}

It is obvious from this short overview of political attitudes that there is no consent of the three constitutive political communities and their elected representatives on the future of the state and on the type of political order in it. Weller 
and Wolff (2006, p. 2) claim that "at least two of its constituent communities Serbs and Croats - thus had little if any real interest in making Bosnia and Herzegovina work as an independent and sovereign member of the international community". Petersen (2011, p. 244) noted "the complete lack of nation building in Bosnia. Very few individuals consider 'Bosnia' as their national homeland". Schneckener (2002, p. 209) points out: "Neither Serbs nor Croats accepted Bosnian statehood [...]". Hence, B-H cannot exist as a self-sustainable state, but only as a protectorate or semi-protectorate of the international community. Almost a quarter of a century from the Dayton Peace Agreement, B-H returned to the 1990s when the main actors established only a consensus on democracy, but a consensus on state, and consequently the one on peace were missing. Moreover, the current consensus on democracy is only principled since the three sides deeply disagree on whether $\mathrm{B}-\mathrm{H}$ should have a liberal or consociational political order and whether it should be a democratic federation or a unitary state. After all, a consensus on democracy does not mean anything if there is no consensus on state. And exactly the absence of a consensus on state was the main cause of the war between 1992 and 1995 and the main cause of the permanent constitutional and political crisis in post-war B-H.

\section{References}

Baer, J. (2000). "Who, Why and How: Assessing the Legitimacy of Secession". Swiss Political Science Review, 6 (3), pp. 45-69.

Bardos, G.N. (2013). Ethnoconfessional Nationalism in the Balkans: Analysis, Manifestation and Management. Bardos_columbia_0054D_11191.pdf (access: 20.12.2016).

Basta, K. (2016). "Imagined Institutions: The Symbolic Power of Formal Rules in Bosnia and Herzegovina”. Slavic Review, 75 (4), pp. 944-969.

Berg, E. (2012). "Parent States versus Secessionist Entities: Measuring Political Legitimacy in Cyprus, Moldova, and Bosnia \& Herzegovina”. Europe-Asia Studies, 64 (7), pp. 1271-1296.

Berg, E. (2013). "Merging Together or Drifting Apart? Revisiting Political Legitimacy Issues in Cyprus, Moldova and Bosnia and Herzegovina". Geopolitics, 18 (82), pp. 467-492.

Bieber, F. (2008). Bosna i Hercegovina poslije rata: Politički sistem u podijeljenom društvu. Sarajevo: Buybook.

Bojkov, V.D. (2003). "Democracy in Bosnia and Herzegovina: Post-1995 Political System and its Functioning". Southeast European Politics, 4 (1), pp. 41-67.

Bose, S. (2002). Bosnia after Dayton. New York: Oxford University Press.

Caspersen, N. (2012). Unrecognized States: The Struggle for Sovereignty in the Modern International System. Cambridge: Polity Press.

Chandler, D. (2000). Bosnia: Faking Democracy After Dayton. London: Pluto Press. 
Chollet, D. (2007). Tajna povijest Daytona, Zagreb: Golden marketing-Tehnička knjiga. Cohen, L.J. (1998). "Whose Bosnia? The Politics of Nation Building". Current History, 97 (617), pp. 103-112.

Dahl, R.A. (1971). Poliarchy: Participation and Opposition, Berkeley: University of California Press.

Dodik, M. (2011). “Disolucija BiH neminovna stvar”. Argumenti, 5 (12), pp. 13-21.

Gromes, T. (2007). Demokratisierung nach Bürgerkriegen. Das Beispiel Bosnien und Herzegowina. Frankfurt-New York: Campus Verlag.

Gromes, T. (2011). “Demokratisierung trotz fehlender Voraussetzungen? Bosnien und Herzegowina, Kosovo und Mazedonien im Verglech”. Zeitschrift für Vergleichende Politikwissenschaft, 5 (2), pp. 253-276.

Hale, H.E. (2004). "Divided We Stand: Institutional Sources of Ethnofederal State Survival and Collapse”. World Politics, 56 (2), pp. 165-193.

Hayden, R.M. (2005). “'Democracy' without a Demos? The Bosnian Constitutional Experiment and the Intentional Construction of Nonfunctioning States". East European Politics and Societies, 19 (2), pp. 226-259.

Hoare, A.M. (1997). “The Croatian Project to Partition Bosnia-Herzegovina, 19901994”. East European Quarterly, 31 (1), pp. 121-138.

Kasapović, M. (2005). "Bosnia and Herzegovina: Liberal or Consociational Democracy?” Croatian Political Science Review, 42 (5), pp. 3-30.

Kasapović, M. (2016). "Lijphart and Horowitz in Bosnia and Herzegovina. Institutional Design for Conflict Resolution or Conflict Reproduction?” Croatian Political Science Review, 53 (4), pp. 174-190.

Keranen, O. (2014). "Building States and Identities in Post-Conflict States: Symbolic Practices in Post-Dayton Bosnia”. Civil Wars, 16 (2), pp. 127-146.

Kohlmann, E.F. (2004). Al Qaida's Jihad in Europe: The Afghan-Bosnian Network. Oxford: Berg.

Kølsto, P. (2006). “The Sustainability and Future of Unrecognized Quasi-States”. Journal of Peace Research, 43 (6), pp. 723-740.

Komšić, I. (2006). Preživljena zemlja. Zagreb: Prometej.

Linz, J.J. (1997). “Democracy Today: An Agenda for Students of Democracy”. Scandinavian Political Studies, 20 (2), pp. 115-134.

Linz, J.J., Stepan, A. (1992). "Political Identities and Electoral Sequences: Spain, the Soviet Union, and Yugoslavia”. Deadalus, 121 (2), pp. 123-139.

Linz, J.J., Stepan, A. (1996). Problems of Democratic Transition and Consolidation. Baltimore: Johns Hopkins University Press.

Marshall, T.H. (2009). “Citizenship and Social Class”. In: J. Manza, M. Sauder (eds.). Inequality and Society. New York: W.W. Norton \& Co., pp. 148-154.

Mearsheimer, J.J., Van Evera, S. (1995). "Even Peace Means War”. The New Republic, 18.12.1995, pp. 16-21. 
Møller, J., Skaaning, S.-E. (2011). “Stateness first?”. Democratization, 18 (1), pp. 1-24.

O’Donnell, G. (2001). “Democracy, Law, and Comparative Politics”. Studies in Comparative International Development, 36 (1), pp. 7-36.

Ó Tuathail, G., O’Loughlin, J., Djipa, D. (2006). “Bosnia-Herzegovina Ten Years after Dayton: Constitutional Change and Public Opinion”. Eurasian Geography and Economics, 47 (1), pp. 61-75.

Pegg, S. (2004). "From de Facto States to States-Within States: Progress, Problems, and Prospects”. In: P. Kingston, I. Spears (eds.). States within States: Incipient Political Entities in the Post-Cold WarEra. Basingstoke: Palgrave Macmillan, pp. 35-46.

Petersen, R.D. (2011). Western Intervention in the Balkans: The Strategic Use of Emotion in Conflict. Cambridge: Cambridge University Press.

Rajčević, S. (2012). “Deset pogleda na budućnost Republike Srpske”. Argumenti (April), pp. 163-190.

Reuter, J. (1997). “Die Bosnisch-Kroatische Föderation. Künstliches Gebilde oder lebensfähiger Staat?” Südosteuropa, 46 (3-4), pp. 158-169.

Ribičič, C. (2001). Geneza jedne zablude. Zagreb: Jesenski i Turk.

Schneckener, U. (2002). "Making Power-Sharing Work: Lessons from Successes and Failures in Ethnic Conflict Regulation”. Journal of Peace Research, 39 (2), pp. 203-228.

Schumpeter, J.A. (1976). Capitalism, Socialism and Democracy. London-New York: Routledge.

Skalnik Leff, C. (1999). "Democratization and Disintegration in Multinational States: The Breakup of The Communist Federations”. World Politics, 51 (2), pp. 205-235.

Stepan, A. (2001). Arguing Comparative Politics. Oxford: Oxford University Press.

Weller, M., Wolff, S. (2006). “Bosnia and Herzegovina Ten Years after Dayton: Lessons for Internationalized State Building”. Ethnopolitics, 5 (1), pp. 1-13.

Zahar, M.-J. (2004). “Republika Srpska”. In: T. Bahcheli, B. Bartmann, H. Srebnik (eds.). De Facto States: The Quest for Sovereignty. London-New York: Routledge, pp. 32-51. 